\title{
INTRAVITREAL TRIAMCINOLONE ACETONIDE AS ADJUNCTIVE TREATMENT FOR NEOVASCULAR GLAUCOMA
}

\author{
Maria Teresa Brizzi Chizzotti Bonanomi, and Remo Susanna Jr.
}

\begin{abstract}
Neovascular glaucoma is a challenging disease in its pathogenesis and treatment. ${ }^{1-3}$ Ischemic retinopathies can lead to neovascular glaucoma due to newly formed vessels on the iris surface and anterior chamber angle. Eyes with neovascular glaucoma can exhibit high intraocular pressure, usually treated by retinal coagulation, cyclodestructive procedures, or drainage procedures. ${ }^{3,4}$ Based on experimental studies, clinical observations, and pathogenetic considerations, Robert Machemer proposed the intravitreal application of crystalline cortisone to locally suppress intraocular inflammation, proliferation of cells, and neovascularization. ${ }^{5-7}$ The purpose of the present clinical study is to report on a new potential treatment modality, the intravitreal injection of triamcinolone acetonide as adjunctive therapy of secondary neovascular glaucoma.
\end{abstract}

\section{CASE REPORT}

A 70-year-old caucasian diabetic woman presented with poor vision in both eyes in September, 2003. Her past ocular history comprised cataract surgery and laser photocoagulation in both eyes for diabetic retinopathy and in the right eye for associated venous occlusion. The diabetes and the high blood pressure were poorly controlled, and creatinine clearance and $\mathrm{HbA} 1 \mathrm{c}$ were $60 \mathrm{~mL} / \mathrm{min}$ and $15 \%$, respectively. Her visual acuity was counting fingers in the right eye (RE) and 20/200 in the left eye (LE). The intraocular pressure (IOP) was $13 \mathrm{~mm} \mathrm{Hg}$ in the RE and 14 $\mathrm{mm} \mathrm{Hg}$ in the LE. The fundus showed bilateral panretinal photocoagulation (PRP) and clinically significant macular

Department of Ophthalmology, Hospital das Clínicas, Faculty of Medicine, University of São Paulo - São Paulo/SP, Brazil.

E-mail: mtbonanomi@uol.com.br edema but no retinal neovascularization (Fig.1). An intravitreal triamcinolone injection was proposed initially for the right eye. An intravitreal injection of $4 \mathrm{mg}(0.1 \mathrm{~mL})$ triamcinolone acetonide (Kenalog-40, Apothecon, Princeton, NJ) was performed through the pars plana. After the procedure (October 17, 2003), her vision did not improve despite the partial drying of the macula, and the intraocular pressure ranged from 12 to $18 \mathrm{~mm} \mathrm{Hg}$ up to February 25,2004 . The LE was treated only with extra peripheral and macular photocoagulation. On March 10, 2004, the patient returned with a severe pain in the RE associated with nausea. Iris neovascularization, cornea edema with poorly visible fundus, and an IOP of $54 \mathrm{~mm} \mathrm{Hg}$ was detected. A second intravitreal injection of $4 \mathrm{mg}$ triamcinolone was given on that day, along with transconjunctival cryotherapy in the peripheral retina ( 5 applications per quadrant). The medical treatment comprised $0.5 \%$ timolol maleate and $1 \%$ atropine locally and oral acetazolamide. After 2 days, the patient returned with no pain, an IOP of

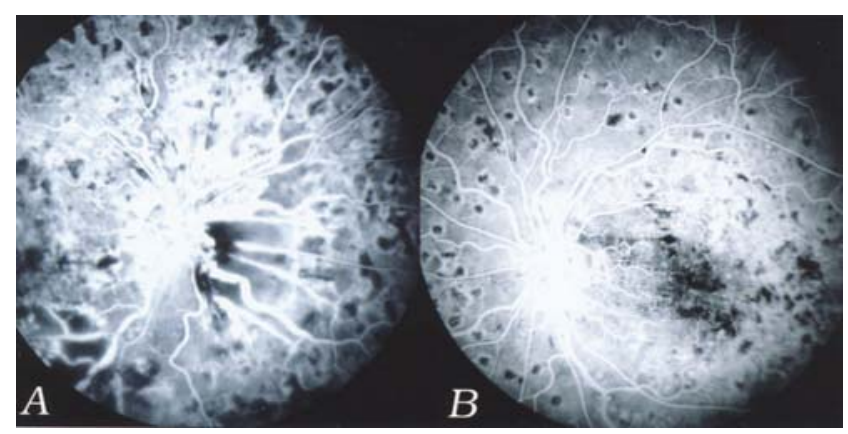

Figure 1 - Angiofluoresceinography of both eyes in September 2003. A - The right eye shows dilated veins alongside the background diabetic retinopathy. Laser marks and large areas of capillary nonperfusion are visible throughout the mid-peripheral retina. B - The left eye shows the diabetic background retinopathy and a less coarse laser pattern 
$24 \mathrm{~mm} \mathrm{Hg}$, no corneal edema, and barely visible iris neovascularization. In the fundus, a progression of the vascular occlusion was visible, now compromising the retinal arteries (Fig.2), and PRP was intensified. In the following visits (April 16, 2004 and May 24, 2004), the IOP was 22 $\mathrm{mm} \mathrm{Hg}$ with $1 \%$ brinzolamide, $0.5 \%$ timolol maleate, and $1 \%$ atropine. The angle was free from goniosynechia in about $120^{\circ}$, and the vision remained the same.

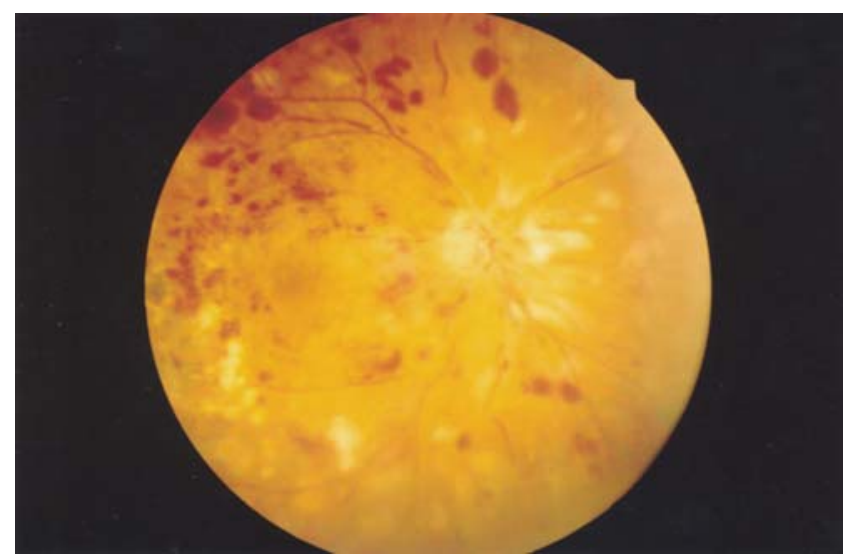

Figure 2 - Color retinography of the right eye after the cryoablation and the intravitreal injection. Two days before this picture, before the treatment, the cornea was edematous and the fundus barely visible. Vascular changes such as venous sheathing, intravascular stop of the blood column, arteriolar thinning, retinal hemorrhages, and cotton wool spots were also visible throughout the entire fundus

\section{DISCUSSION}

One of the most important still unsolved problems in clinical ophthalmology is the proliferation of vascular cells in eyes with intraocular neovascular diseases. The new vessels on the iris surface and anterior chamber angle are secondary to ischemic and, to a lesser degree, to inflammatory retinal diseases. ${ }^{1}$ Once established, this entity is difficult to manage surgically.$^{2}$ The arresting of the neovascular process through retinal destructive techniques is the only known treatment. ${ }^{3}$ Even though retinal ablation has an efficacy of about $85 \%$ using cryosurgery or laser surgery; neovascular glaucoma may still appear in $1.6 \%$ of treated eyes. ${ }^{4} \mathrm{~A}$ specific pharmacological therapy for intraocular neovasularization control or regression is not still available. For many years, corticosteroids have been known to reduce intraocular inflammation and, depending on the concentration, to suppress cell proliferation. Consequently, corticosteroids, given either locally or systemically, have been used in many ocular conditions. To achieve the highest concentration of a drug at its site of action, however, it is best to give it directly into the area where this action is required. Based on experimental studies that showed steroid inhibition of appearance and growth of neovascular tis- sue in the eye due to inflammation ${ }^{5-8}$ and ischemia, ${ }^{9}$ along with its few described side effects. ${ }^{10,11}$ Jonas et al. proposed the intravitreal injection of crystalline cortisone as an adjunctive therapy to manage neovascular glaucoma. ${ }^{12}$ They reported using a single injection of approximately $20 \mathrm{mg}$ of triamcinolone acetonide with little vehicle in patients with established neovascular glaucoma. Associated procedures included goniosynechiolysis, phacoemulsification and intraocular lens implantation, and transscleral peripheral retinal cryocoagulation. After a follow-up period of 3.10 \pm 2.4 months, they showed a significant decrease of the degree of rubeosis iridis, improvement in intraocular pressure, and no significant changes in visual acuity.

Recently, a smaller amount of triamcinolone $(0.1 \mathrm{~mL}$ of $40 \mathrm{mg} / \mathrm{mL}$ ) with no previous filtration has been injected into the vitreous, to control macular edema secondary to diabetes, ${ }^{13}$ central retinal vein occlusion (CRVO),${ }^{14}$ and inflammatory disease. ${ }^{15}$ Despite the potentially vision-threatening complications such as transient or persistent intraocular high pressure, ${ }^{16}$ cataract progression, ${ }^{13}$ and aseptic $^{17}$ or septic endophthalmitis, ${ }^{18}$ the gravity of the clinical condition of our patient seemed to justify this procedure. We performed a single injection of $4 \mathrm{mg}$ of the commercially available triamcinolone acetonide through the pars plana along with transconjunctival cryotherapy. Our patient received 2 injections, and it may be speculated that the first injection caused a worsening of the neovascular process. Although it has frequently been a surgical approach, intravitreal corticosteroid injection has not been associated with this complication in the literature. ${ }^{13-20}$ Ip et al., ${ }^{20}$ retrospectively studying 13 patients treated with $4 \mathrm{mg}$ intravitreal triamcinolone injections to control macular edema due to central retinal vein occlusion, reported a second injection in 3 patients and 1 eye that developed iris neovascularization after the treatment. In our patients, in the 2 days after the injection, the iris neovascularization was barely visible, the corneal edema was gone, and we could complete the PRP through clear media. It has to be taken into account that the duration of the anti-angiogenic effect of the intravitreal steroids is limited about 2 weeks experimentally ${ }^{21,22}$ and from 2 to 5 months clinically ${ }^{13,14}$ if not supported by additional procedures such as panretinal photocoagulation.

In the present case, it is unlikely that the rapid iris neovascularization regression, as well as the reduction in IOP, was caused solely by the retinal cryocoagulation. Though consistently stating the efficacy of this method of treatment for anterior segment neovascularization or early neovascular glaucoma, the literature is not clear about the time span in which neovascularization regression takes place. ${ }^{23-25}$ Using the panretinal cryotherapy (10 to 14 ap- 
plications per quadrant), the regression of the rubeotic vessels begins after a few days of treatment, with complete resolution occurring after 4 to 6 weeks. ${ }^{23,24}$ Using the transconjuntival anterior retina cryoablation, Sihota et al. ${ }^{25}$ report a rapid release of pain and iridocyclitis, with the corneal edema regressing over a period of 7 to 10 days. In our patient, after 48 hours of the treatment pain, iris neovascularization and corneal edema were all gone, leaving a perfect environment for further retinal photocoagulation (Fig. 2).

The results of this study support the findings of previous investigations and clinical observations. ${ }^{11}$ Using the intravitreal cortisone injection associated with the cryotherapy, we gained time and were able to stop the process of angle closure through retinal coagulation.

The outcome of this case, as well as evidence from the literature, suggests that the intravitreal application of triamcinolone acetonide helps to temporarily reduce the neovascularization of the iris. With the normalization of the intraocular pressure and clearing of the corneal edema, laser application to the retina is possible through clear media.

However, randomized prospective investigations are needed to confirm our findings and to determine the usefullness of the intravitreal injection of $4 \mathrm{mg}$ of triamcinolone acetonide as an additional tool in the treatment of neovascular glaucoma secondary to ischemic retinopathies.

\section{AKNOWLEDGMENTS}

We thank Miss Leonor Maria Dias Sampaio for the language revision.

\section{REFERENCES}

1. Brown GC, Magargal LE, Schachat A, Shah H. Neovascular glaucoma. Etiologic considerations. Ophthalmology. 1984;91:31520

2. Susanna Jr R and the Latin American Glaucoma Society (SLAG) investigators. Partial Tenon's capsule resection with adjunctive mitomycin $\mathrm{C}$ in Ahmed glaucoma valve implant surgery. Br J Ophthalmol. 2003;87:994-8.

3. Sivak-Callcott JA, O`Day DM, Gass DM, Tsai JC. Evidence-based recommendations for the diagnosis and treatment of neovascular glaucoma. Ophthalmology. 2001;108(10):1767-76.

4. Fernandez-Vigo J, Castro J, Macarro A. Diabetic íris neovascularization. Natural history and treatment Acta Ophthalmol. 1997;75:89-93.

5. Machemer R, Sugita G, Tano Y. Treatment of intraocular proliferations with intravitreal steroids. Trans Am Ophthalmol Soc. 1979;77:171-80.

6. Tano Y, Sugita G, Abrams G, Machemer R. Inhibition of intraocular proliferation with intravitreal corticosteroid. Am J Ophthalmol. 1980;89:131-6.

7. Tano Y, Chandler D, Machemer R. Treatment of intraocular proliferation with intravitreal injection of tramcinolone acetonide. Am J Ophthalmol. 1980;90:810-6.

8. Antoszyk AN, Gottlieb JL, Machemer R, Hatchell DL. The effects of intravitreal triamcinolone acetonide on experimental pre-retinal neovascularization. Graefe's Arch Clin Exp Ophthalmol. $1993 ; 231: 34-40$.

9. Danis RP, Bingaman, DVM, Yang, Y, Ladd B. Inhibition of preretinal and optic nerve head neovascularization in pigs by intravitreal triamcinolone acetonide. Ophthalmology. 1996;103:2099-104.
10. McCuen BW 2d, Bessler M, Tano Y, Chandler D, Machemer R. The lack of toxicity of intravitreally administered triamcinolone acetonide. Am J Ophthalmol. 1981;91:785-8.

11. Hida T, Chandler D, Arena JE, Machemer R. Experimental and clinical observations of the intraocular toxicity of commercial corticosteroid preparations. Am J Ophthalmol. 1986;101:190-5.

12. Jonas JB, Hayler JK, Söfker A, Panda-Jonas S. Regression of neovascular iris vessels by intravitreal injection of crystalline cortisone. J Glaucoma. 2001;10:284-7.

13. Martidis AM, Duker JS, Greenberg PB, Rogers AH, Puliafito CA, Reichel E, et al. Intravitreal Triamcinolone for refractory diabetic macular edema. Ophthalmology. 2002;109:920-7.

14. Greenber PB, Martidis A, Rogers AH, Duker JS, Reichel E. Intravitreal triamcinolone acetonide for macular oedema due to central retinal vein occlusion. Brit J Ophthalmol. 2002;86:247-8.

15. Godoy G, Finamor LP, Andrade R, Muccioli C. Triancinilona intravítrea em vasculite retiniana - Relato de caso. Arq Bras Oftalmol. 2004;67(6):953-5.

16. Smithen LM, Ober MD, Maranan L, Spaide RF. Intravitreal triamcinolone acetonide and intraocular pressure. Am J Ophthalmol. 2004;138:740-3.

17. Moshfeghi DM, Kaiser PK, Bakri SJ, Kaiser RS, Maturi RK, Sears JE, et al. Presumed sterile endophthalmitis following intravitreal triamcinolone acetonide injection. Ophthalmic Surg Lasers Imaging. 2005; 36:24-9.

18. Simpson JM, Gillies MC. Intravitreal triamcinolone for diabetic macular edema that persists after laser treatment: three-month efficacy and safety results of a prospective, randomized, double masked, placebo-controlled clinical trial. Ophthalmology. 2004;111:2044-9. 
19. Park CH, Jaffe GJ, Fekrat S. Intravitreal triamcinolone acetonide in eyes with cystoid macular edema associated with central retinal vein occlusion. Am J Ophthalmol. 2003;136:419-25.

20. Ip MS, Gottlieb JL, Kahana A, Scott IU, Altaweel MM, Blodi BA, et al. Intravitreal triamcinolone for the treatment of macular edema associated with central retinal vein occlusion. Arch Ophthalmol. 2004; 122:1131-6.

21. Schindler RH, Chandler DB, Thresher R, Machemer R. The clearance of intravitreal triamcinolone acetonide. Am J Ophthalmol. $1982 ; 93 ; 415-7$.
22. Scholes GN, O`Brien WJ, Abrams GW, Kubicek MF. Clearence of triamcinolone from vitreous. Arch Ophthalmol. 1985;103:1567-9.

23. Vernon SA, Cheng H. Panretinal cryotherapy in neovascular disease. Br J Ophthalmol. 1988;72:401-5.

24. Stefaniotou M, Paschides CA, Psilas K. Panretinal cryopexy for the manegement of neovascularization of the iris. Ophthalmlogica. 1995;209:141-4.

25. Sihota R, Sandramouli S, Sood NN. A prospective evaluation of anterior retinal cryoablation in neovascular glaucoma. Ophthalmic Surg. 1991;22:256-9. 